\title{
JAZZ ON PORTUGUESE FILM BELARMINO (1964) AND ALICE (2005) - TWO MILESTONES
}

\author{
Pedro Cravinho \\ INET-md/Universidade de Aveiro \\ José Dias \\ INET-md/Universidade Nova de Lisboa
}

\section{INTRO: BELARMINO AND ALICE - MILESTONES IN PORTUGUESE FILM}

In a wide perspective over the history of Portuguese film, both Belarmino and Alice play decisive roles. If the first is an inescapable reference for understanding what Portuguese Cinema Novo (New Cinema) was and what kind of artistic rupture was taking place in the 1960's in Portugal, the second also marks a breakup from former Portuguese film-making and a rapprochement to broader film audiences. The fact that both films have jazz music as soundtracks comes not just as chance, but as a relevant circumstance. Both films and their music form a wealth of information about Portuguese society and its jazz community at two different times: in the sixties under Salazar's dictatorial Estado Novo regime; and in the beginning of the $21^{\text {st }}$ century as a full member of the European Union.

Belarmino, released in $1964^{1}$, is the first feature film by Fernando Lopes, who had previously worked on cinema and TV. ${ }^{2}$ The film's narrative explores the life and the imagination of Portuguese former amateur light middleweight boxer Belarmino Fragoso, who became a Lisbon minor celebrity at the late 1950's and early 1960's. Belarmino is a documentary with some fictional ingredients, since the action is based on a verbal testimony from the main character (non-actor), which interprets and re-interprets himself as a boxer. The film is a 'hybrid between documentary and fiction' (Areal, 2012:399) and a good example of how, 'in documentaries, the complex relationship between fiction, nonfiction and documentary as categories overlap' (Ward, 2005:31). More than a biographic tour on the life of a former Portuguese boxer, it takes

1 This film was premiered in Lisbon in the Avis Cinema on 18 $8^{\text {th }}$ November 1964.

2 On cinema: 1) as assistant director: Azulejos de Portugal (1958), and A Paixão de Cristo na Pintura Antiga Portuguesa (1959); 2) as director: The Bowler Hat (1960), Interlude (1960), and The Lonely Ones (1960) [These three Fernando Lopes films were made in London as part of his course at the London School of Film Technique]; As Pedras e o Tempo (1960), O Voo da Amizade (19602), and As Palavras e os Fios (1962). On television: as director on Portuguese Public Television: Cidade das Sete Colinas (1962) TV Series. 
us through a journey between reality and fiction on Lisbon's mid-sixties' nightlife, where places such as dance halls, nightclubs, strip clubs, and boxing rings were not only a part of Belarmino Fragoso's métier but also of a new generation of Portuguese Lisbon based artists' lifestyle.

Manuel Jorge Veloso ${ }^{3}$ was chosen to write and perform the score. A classically trained musician (violin and composition), he started as an amateur jazz drummer before becoming a national jazz icon. At the time, he was a member of the Hot Clube de Portugal Quartet. Connections between Jorge Veloso and Fernando Lopes go back to previous years, when they both began working at the Radiotelevisão Portuguesa (Portuguese Public Television): Fernando Lopes as an assistant editor, in 1957; and Jorge Veloso as musical production assistant, in 1958. Despite Belarmino being the first Portuguese feature film incorporating a jazz soundtrack, a first experience in this field also belongs to Fernando Lopes (director) and Jorge Veloso (composer and musician) two years earlier in the short film As Palavras e os Fios, in 1962.

Alice, released in 2005, is the first feature film by Marco Martins, who had previously directed four short films ${ }^{4}$. The plot explores a fathers' obsession trying to locate his young daughter Alice trough Lisbon and walking every day the path they did the day she disappeared, giving us a gloomy, repetitive look over the city's daily experience. Featuring Portuguese actors Nuno Lopes and Beatriz Batarda as the young couple, it shows us the disturbed relationship between both parents after losing their child. Alice became noticed in several film festivals and won quite a few notorious awards ${ }^{5}$. It is considered a landmark in the early $21^{\text {st }}$ century's Portuguese cinema, and the first of his generation to gain attention from the international critic ${ }^{6}$. Also, after several decades where Portuguese cinema had been detached from wider audiences ${ }^{7}$, this generation of young directors achieved relevant box office figures and public recognition.

3 Manuel Jorge Souto de Sousa Veloso (b. Lisbon 1937). His collaboration as a film score composer include: 1) Short-films - As Palavras e os Fios (Fernando Lopes 1962); Faça segundo a Arte (Faria de Almeida 1965); A Embalagem de Vidro (Faria de Almeida 1966); Triunfo da Técnica (Faria de Almeida 1970); Vida e Obra de Ferreira de Castro (Faria de Almeida 1971); 2) Feature films - Belarmino (Fernando Lopes 1964); Uma Abelha na Chuva (Fernando Lopes 1968-1969); and Pedro Só (Alfredo Tropa 1971). As director [These three Manuel Jorge Veloso short-films were made in German Democratic Republic as part of his course at the Hochschule für Film und Fernsehen in Potsdam-Babelsberg] Beruehrungen (1982); Ich wag den Traum (1983); and Noch sieben Jahre muss ich wandern (1984).

4 Mergulho no Ano Novo (1992), Não Basta Ser Cruel (1995), Clockwise (1996), and No Caminho Para a Escola (1998).

5 Director's Fortnight Best Movie Award 2005 - Cannes Film Festival; Jeunes Regardes Award 2005 Cannes Film Festival; Best Director - First Work 2006 - Las Palmas de Gran Canaria International Film Festival; Best Director 2006 - Mar del Plata Film Festival; Best Director 2006 - Raindance Film Festival, Best Filmography and FIPRESCI Prize 2006 - Mar del Plata Film Festival; Shooting Star (Nuno Lopes) Award 2006 - Berlin International Film Festival; nominated for the Fassbinder Award 2005 - European Film Awards; nominated for Best Film 2005 - Mar del Plata Film Festival; and submitted for the 79th Academy Awards 2007 for the Academy Award for Best Foreign Language Film.

6 Other sequential Portuguese non-commercial, author films include Sangue do Meu Sangue (2011), by João Canijo, awarded with Best Film Prize at the San Sebastian International Film Festival, the Palm Springs International Film Festival, and the Miami International Film Festival; Tabu (2012), by Miguel Gomes, awarded with the Alfred-Bauer-Preis and the FIPRESCI Prize at the Berlin International Film Festival; and Rafa (2012), by João Salaviza, awarded with the Golden Bear for Best Short Film at the Berlin International Film Festival.

7 Portuguese cinema, since the seventies until the late nineties, became almost exclusively engaged with experimentalism and/or exploring the relationship between film and the theatre, like in the works of Manoel de Oliveira (n.1908) and João César Monteiro (n.1939 - d.2003).

Quaderns, 9 (2014), pp. 43-50 
Bernardo Sassetti ${ }^{8}$, one of the most accomplished Portuguese jazz musicians, pianist and composer - but also a known amateur photographer, director and cinema aficionado -, was chosen to write and perform the score. As we will see further ahead, Sassetti was one of the Portuguese jazz musicians who, in the beginning of the $21^{\text {st }}$ century, initiated an aesthetic approach to European jazz and some deviation from the American jazz tradition. His passing away quite recently, only 41 years old and at the peak of his creativity, makes this also one of the first exploratory studies on his music.

\section{RESEARCH APPROACH}

Based on the principle that 'every film is ethnographic' (Slobin, 2008:3-4), this article aims to make ethnography of Portuguese jazz and society through film music in two decisive periods of its history. If in a broader sense "one or two notes in a distinctive musical style are sufficient to target a specific social and demographic group and to associate a whole nexus of social and cultural values with a product" (Cook, 1998:16-17), that is not absolutely true for both films analysed here. In Belarmino, though jazz conveys very specific social values, it appears as a music genre closer to the identity of the director and the production team than to the feature main character itself. And in Alice, though music relays precise attitudinal messages, it has more of an emotional function than it socially contextualizes the narrative. In that sense, we may say that both Veloso's and Sassetti's scores, by aiding formal and narrative blending, do provide an 'aesthetic unity'9 (Gorbman, 1998:73). But while in Belarmino music acquires 'rhetorical factors' ${ }^{\prime 10}$, making a recognizable contrast with the narrative (Wingstedt, 2008: 32), in Alice music is a 'signifier of emotion' itself (Gorbman, 1998:73), setting specific moods and accentuating particular emotions suggested in the storyline.

\section{DIFFERENT SCORES, DIFFERENT (JAZZ) COMMUNITIES}

The relationship between the auditory and visual components in cinema is both active and dynamic, affording a multiplicity of possible relations than can evolve - sometimes dramatically - as the narrative unfolds (Lipscomb \& Tolchinsky, 2005).

8 Bernardo da Costa Sassetti Pais (n.1970 - d.2012). His collaboration as a film score composer include Maria do Mar (Leitão Barros 1930) a silent film with Sassetti's score composed in 2000 for its restored copy and special screening, Facas e Anjos (Eduardo Guedes 2000), Quaresma (José Álvaro Morais 2003), O Milagre Segundo Salomé (Mário Barroso 2004), A Costa dos Murmúrios (Margarida Cardoso 2004), the documentary Noite em Branco (Olivier Blanc 2004) and the short-filme As Terças da Bailarina Gorda (Jeanne Waltz 2000). As soloist, he's featured in Pax (Eduardo Guedes 1994), The Talented Mr. Ripley (Anthony Minguella 1999) and in the short-film Bloodcount (Bernard McLoughlan 1999).

9 Although Claudia Gorbman addresses mainly classical film music, we consider that in this case the musical genre is irrelevant. According to the author, in the traditional narrative cinema, music's main function is to involve the viewer emotionally, disarming his critical thinking and putting him "inside" the film (1998:73).

10 Swedish composer, Johnny Wingstedt, in his book Narrative Music: On Functions of, and Knoledge about, Narrative Music in Multimedia (2008), establishes a hierarchy that is more detailed than Claudia Gorbman's. Unlike Gorbman, Wingstedt seems to have deduced his theory from his practice as a film music composer, since the functions he presents are more pragmatic. He proposes three different groups of functions - Ideational Meaning (emotional, informative, descriptive); Interpersonal Meaning (emotional, guiding, rhetoric); and Textual Meaning (temporal and intermodal) (2008:47). 


\section{PORTUGUESE FILM AND ITS SCORES}

According to Jorge de Sá Gouveia, in Portugal, "from the 1930's through 50's, film music was clearly inspired on the Hollywood model", were classical composers frequently worked for the cinema industry (Gouveia, 2011) ${ }^{11}$. However, this statement may seem contradictory, because on one hand, as José Manuel Sardica referred in his study Twentieth Century Portugal - A Historical Overview, "Salazar never liked the Americans, and especially the types of civilization and culture the USA stood for"(Sardica, 2008:67), on the other hand, according to Gouveia, the film music composed for Portuguese cinema, over nearly two decades, and funded by the Estado Novo regime, clearly had a strong influence of North American cinema. In fact, since 1933, with António Salazar in the leadership, Portugal became a dictatorial regime known as Estado Novo (New State). Antonio Costa Pinto (a specialist on the New State) refers that "although some of the institutional construction of Salazarism was inspired by the fascism in power, particularly that of Italy, it adopted the elements which tended to unite right-wing dictatorships of the period" (Pinto, 1992:79). With the strong Salazar influence, as Sardica asserts, the Portuguese "'patriarchal and masculine society' were framed by the 'dominant rural ethos' proposed by Salazar (Sardica, 2008:73). Given the role that the Church and Catholicism had in promoting the values of the regime: "God, Fatherland and Family"; the regime made use of film as a promoter of a collective morality rooted in the virtues of peaceful obedience and puritanical behavior (Pinto, 2003). In a same note, Gouveia notes:

There were no Portuguese film noir, and Italian neo-realism was badly mutilated. The truth was as politically distorted as a soviet propaganda film with a twist. Music ruled this micro cosmos. If someone would analyze Portugal through these movies, one would say that these were probably the most musical people on earth. All because almost all popular films of that period made in Portugal were...musicals (2011).

As result, the Portuguese cinema during this period, although it was inspired in the Hollywood models, "the plot was quite simple, structured in three acts and the characters were social stereotypes" (Gouveia, 2011).

\section{BELARMINO - CINEMA NOVO AND JAZZ IN PORTUGAL IN 1960'S}

Since the end of the Second World War, in the metropolitan Lisbon area, gradually a musical jazz scene supported by musicians from several different musical areas such as: professional musicians from night-clubs and dance halls; jazz amateurs; classically trained musicians; and sporadically, foreign jazz musicians, started to emerge. The approval of the statutes of the Hot Clube de Portugal by the Lisbon Civil Government on March $26^{\text {th }}$ in 1950 would potentiate the organization of several jam sessions, concerts and jazz festivals, mainly in Lisbon area during next decades ${ }^{12}$. In

11 Composers like Frederico de Freitas (Francisco Ribeiro's O Pátio das Cantigas), Raul Ferrão (A Aldeia da Roupa Branca) or Jaime Lopes (O Leão da Estrela, O Costa do Castelo) were responsible for the production of the most of the songs, and melodies that stayed on the Portuguese collective memory, even in the future generations who only saw those films on television (Gouveia, 2011).

12 The first jazz festival in Lisbon on July $27^{\text {th }}, 1953$ - organized by the Hot Clube de Portugal, named "Modern Music Festival"; The second jazz festival in Portugal on April $5^{\text {th }}, 1954$ - organized by the Hot Clube de 
this sense the foundation of the Hot Clube de Portugal, as centre of the Lisbon's jazz scene, as Jackson's definition,

A socially constructed arena within which mainstream jazz performance occurs and is made possible [...]. It's a fluid network within which a variety of actors and institutions negotiate their relationships with each other and those outside their network. Simultaneously, all involved are negotiating relationships with the history of music (Jackson, 1998),

would definitely contribute both to the consolidation of a new generation of Portuguese amateurs jazz musicians Lisbon based, and at the same time, to the diversity nightlife during the late 1950 and 1960's decades ${ }^{13}$. Manuel Jorge Veloso (chosen to write and perform the score) would become a part of this emergent jazz scene as member of the Hot Clube de Portugal Quartet (drummer). ${ }^{14}$ At the same time, in 1958, Jorge Veloso initiated his professional activity as assistant musical producer for Portuguese Public Television (Cravinho, 2013a). Regular transmissions by Portuguese Public Television -Radiotelevisão Portuguesa- began on the $7^{\text {th }}$ March 1957. During these early years of activity, both Belarmino director and musical composer -Fernando Lopes (February 1957), and Manuel Jorge Veloso (May 1958)-, become part of the Portuguese Television pioneer team, until Fernando Lopes leave to the London Film School with a full grant from the Portuguese Fundo Cinema Nacional, were he would stay, until 1961. Meanwhile, during this period Jorge, Veloso would be responsible for the production for most jazz music programs broadcast by the Portuguese television between 1958 and 1963 (Cravinho, 2013b). After Fernando Lopes London experience, where he made his first films as director, The Bowler Hat (1960), Interlude (1960), and The Lonely Ones (1960), all three films were made as part of his course at the London School of Film, he return in late 1961 to Portugal, to rejoin the Portuguese Public Television. The following years were decisive in consolidating knowledge of both, each in their area, Jorge Veloso, as a jazz musician and composer, Fernando Lopes, as television director, alongside with a third element that would be essential in making Belarmino, the director of photography, Fernando Cabrita.

According to Leonor Areal, the designation 'cinema novo' (new cinema) started as an editorial formulation by some Portuguese journalists aiming to promote the so called 'author film' (Areal, 2012: 367):

"In the early sixties, author film, produced mainly in Europe, assumed the designation 'cinema novo' (new cinema), following the footsteps of the French nouvelle vague; it was new because it was young - regarding its director's ages and their fresh perspective over film-making. (Areal apud Geada, 1977: 92) (15 $^{2}$

Portugal, named "Modern Music Festival"; The Sydney Bechet and Andre Reweliotty Quintet concert on November $2^{\text {th }}, 1955$, in Monumental Theatre at Lisbon; The Count Basie Orchestra and the jazz singer Joe Williams on October $1^{\text {st }}, 1956$, in the Império Cinema; The third jazz Festival in Portugal on July $25^{\text {th }}, 1957$ - organized by the Hot Clube of Portugal, named "Modern Music Festival".

13 This generation of Portuguese amateurs jazz musicians included Ivo Mayer (piano), Rafael Couto (double bass), Luis Esteves (drums), Vasco Henriques (piano), Luis Sangareau (drums), Alfonso Sangareau (double bass), Carlos Menezes (electric guitar), Mário Simões (piano), Helder Reis (piano), Hélder Martins (piano), and many several others.

14 In 1958 the Hot Clube de Portugal Quartet members were: Jean-Pierre Gebler (baritone saxophone); Justiniano Canelhas (piano); Bernardo Moreira (double bass), and Manuel Jorge Veloso (drums).

15 Translated by the authors. 
It was essentially an independent film movement, detached from the conservative ideology and from the classical cinematographic model of Salazar's regime. Fernando Lopes and Belarmino represent an aesthetic revolution in Portuguese film (Areal, 2012: 399).

\section{ALICE - EUROPEAN AESTHETICS IN THE 21ST CENTURY PORTUGUESE JAZZ}

Many people got disappointed by the fact that I now make music that has no swing and is not searching for swing, nor the black tradition, nor black/white, but one with all the different elements jazz in Europe has today. But the fact is that [...] this is only a way. I like to search. I'm always searching (Sassetti 2012, translated by the authors).

Though reluctant to define the music in Alice as jazz, Sassetti acknowledged it as a step towards his musical 'search'16. In that sense, Alice's score can be seen as a determining phase in an aesthetic shift in his music. By choosing an uncharacteristic trio -piano (and crystal glass), double bass and clarinet-, and by introducing impressionistic elements ${ }^{17}$, Sassetti underlines the oneiric and the evocative orientation of his compositions, thus suggesting, above all, the inner mood of the characters. "I can't work with scripts. I need to see the characters' faces and the 'color' of the movie" (Sassetti, 2007, translated by the authors).

For Sassetti, in Alice, almost all of the musical inputs are focused on the reluctant father's feelings, antagonistic to the mothers' reaction, and on the enormous void caused by their daughter's disappearance. Although there is an almost obsessive relationship with time-Sassetti stated that the main theme from the movie was composed in 7/4 time signature, illustrating the seven days of the week and the father's compulsive search for his daughter ${ }^{18}$ - in his view, the sound in this film represents this character's inner silence versus the aggressive urban Lisbon sound that surrounds him daily ${ }^{19}$. As a matter of fact, Sassetti sees his music as a way of smoothening the director's violent portrayal of Lisbon and of underlining the character's feelings, rather than musically illustrating the film's narrative ${ }^{20}$. This option was not unilateral: Marco Martins - the director - extensively worked close to Sassetti while he was composing. In that sense, Alice's score can be seen, on the one hand, as the film's unattached musical work, but, on the other, as having its own purpose other than telling that story in that director's particular perspective.

Sassetti agrees that this music is 'functional', but its function is emotional ${ }^{21}$. By setting specific moods and amplifying what is only suggested by the film, music here provides, more than anything, an 'emotive function' (Gorbman, 1998:73).

16 In an interview for Diário Económico, April 11 th, 2012.

17 Here, we take impressionist elements in music as what Oscar Thompson defines as components that serve «to suggest rather than to depict; to mirror not the object but the emotional reaction to the object; to interpret a fugitive impression rather than to seize upon and fix the permanent reality» (1937:21). Also, recently, Sun Hye Park has characterized impressionist musical composition in four aspects. «[...] dissonances are freely used; [...] the modal scales are widely used: [...] regular movements of rhythmic patterns are absent; [...] tonality is never totally abandoned» (2012:13-14).

18 See Jorge de Sá Gouveia, Sassetti: Music is part of a movie's soul. In http://hdl.handle. net/10400.21/459 (accessed at August 23, 2013)

19 In an interview for the cultural website Bodyspace.net. In http://bodyspace.net/entrevistas/64-bernardosassetti/ (accessed at June, 12, 2013) Translated to English by the authors.

20 In an interview for Diário de Notícias, December 2007

21 Idem.

Quaderns, 9 (2014), pp. 43-50 
Also, the fact that the composer divided the film musically in three 'chapters'22 - each one for the main character's different state of mind - brings the score closer to European music tradition: 'music piece' or suite, divided into movements. In fact, Sassetti defined Alice's main theme and the first two movements as 'minimal music'23.

In Sassetti's own words, Alice was the definite point in his writing process, the one score that made him look into composing in a different way - "with containment", "listening to music's own silence"24.

This shift, though deeply personal for him, was also taking place among other Portuguese jazz musicians of his generation. The clear separation between classical music and jazz, that had been strong until then, was starting, by this point in time, to become hazier. As one of the most prominent jazz musicians of his generation, Sassetti, on the verge of the present century, like most of them, began deviating from a mainstream bop American jazz aesthetic and starting to incorporate more and more European jazz elements and collaborations.

This change in Portuguese jazz results mainly from a jazz education boom that occurred in the country in the beginning of the 2000's, with 4 universities granting jazz undergraduate courses and around new 20 jazz schools across the map, where only two schools existed since the 1980's (Dias 2009). Also the fact that some of these musicians studied jazz abroad in Europe helped creating a network inside and outside Portugal. Although Sassetti himself never attended a jazz school, he lived in Paris, London and Barcelona where he began collaborating still very young with local and American musicians. In a way, doing so in the mid-nineties, he became, for Portuguese jazz musicians, a pioneer in networking and collaborating among Europeans.

\section{CONCLUSIONS}

Though the Salazar regime showed vivid signs of retraction before foreign influences in the various domestic forms of culture, American music was a very relevant inspiration for score composers working in Portugal. Jazz-inspired scores can be heard in Portuguese film as far as the 1940s. However, it was only with Belarmino that jazz, not only as music but also as a cultural reference, was made an intricate part of a Portuguese movie as a whole. Unfortunately and according to Ana Leal, the documentary style started by Fernando Lopes with Belarmino

wouldn't leave any direct legacy in Portuguese film; only after the 1974 revolution, and with the dissemination of the free documentary, very few documentaries will show some signs of independence towards the militant discourse which has reigned the genre in that particular period (Areal, 2012: 399).

Recent Portuguese film, now free from aesthetic restrictions, only uses jazz residually. Alice's music, though not assumed as a jazz score, reflects new ways of perceiving contemporary music influences. The music genre is second to the intention of the composer and the director.

Veloso and Sassetti were major references in different and definite times of Portuguese jazz's history. The first was a pioneer of the genre's dissemination; the second became one of the first Portuguese jazz musicians to establish transnational collaborations. Therefore, both their work as musicians and as composers to these two films gains greater importance to the study of jazz and film in Portugal.

22 Ibidem.

23 Ibidem.

24 In an interview for Público, December $18^{\text {th }}, 2005$. 


\section{REFERENCES}

AREAL, Leonor. 2012. Cinema Português - Um país Imaginado. Vol. 1 - Antes de 1974. Lisboa, Edições 70.

CARVALHO, José Carlos. "Bernardo Sassetti: Alice Encontrada", Diário de Notícias - suplemento DN Música, Dec. 16, 2005.

CRAVINHO, Pedro. 2013a. "'Jazz and Television in Portugal: TV JAZZ and the presence of jazz on the Portuguese Public Television of the 1960's and 70's". (Paper presented at Rhythm Changes Conference 'Rethinking Jazz Cultures', United Kingdom, Media City, April, 13th, 2013).

CRAVINHO, Pedro. 2013b. "'Music, Images and Politics: Jazz and Television in Portugal under Salazar Dictatorship (1956-1968)" (Keynote presented at $1^{\circ}$ Congreso Internacional: El Jazz en España 2013, Spain, Universitat de Valéncia, November, 28th, 2013).

COOK, Nicholas. 1998. Analysing Musical Multimedia. Gloucestershire: Clarendon Press.

DIAS, José. 2009. Playing Outside - Jazz e Sociedade em Portugal na Perspectiva de duas Escolas (Master's Thesis). Lisboa, Universidade Nova de Lisboa.

GEADA, Eduardo. 1977. O Imperialismo e o Fascismo no Cinema. Lisboa, Moraes.

GOMES, André. "Bernardo Sassetti, Um pouco mais de azul", in Bodyspace.net. Available from http://bodyspace.net/entrevistas/64-bernardo-sassetti/ (accessed June 12, 2013).

GORBMAN, Claudia. 1998. Unheard Melodies: Narrative Film Music. Indianapolis, Indiana University Press.

GOUVEIA, Jorga de Sá. 2011. "Sassetti: music is part of the movie's soul", in Ensaios - Novas e Velhas Tendências no Cinema Português Contemporâneo, available from http://repositorio.ipl.pt/bitstream/10400.21/459/1/sassetti.pdf (accessed Dec. 2, 2013).

JACKSON, Travis A. 1998. Performance and Musical Meaning: Analysing "Jazz" on the New York Scene (Doctoral Thesis). New York, Columbia University.

LIPSCOMB, S.D. and Tolshinsky, D. E., 2005. "The role of music communication in cinema", in D. Miell, R. MacDonald \& D. Hargreaves (Eds.) Musical Communication. Oxford, Oxford University Press. 383-404.

OLIVEIRA, João Pedro. "Podem piratear os meus discos à vontade", Diário Económico. May 11, 2012. PARK, Sun Hye. 2012. Elements of Impressionism evoked in Debussy and Ravel's "Reflets dans l'eau" and "Jeux d'eau": The theme of water (Doctoral thesis). Washington, University of Washington.

PINTO, António Costa. 1992. "The New State of Salazar: An Overview" in Richard Herr (ed.), The New Portugal Democracy and Europe. Berkley, University of California.

- 2003. "Twentieth Century Portugal: An Introduction" in António Costa Pinto (ed.), Contemporary Portugal Politics, Society and Culture. New York, Columbia UP.

SARDICA, José Miguel. 2008. Twentieth-century Portugal: a historical overview. Lisboa, Universidade Católica Editora.

SEIXAS, Maria João. "Conversa com vista para... Bernardo Sassetti", Jornal Público, Dec. 18, 2005.

SLOBIN, Mark. 2008. Global Soundtracks: Worlds of Film Music. Wesleyan UP.

THOMPSON, Oscar. 1937. Debussy: man and artist. New York, Dodd, Mead and Co.

WARD, Paul. 2005. Documentary The Margins of Reality. New York, Columbia U P.

WINGSTEDT, Johnny. 2008. Narrative Music: On Functions of, and Knoledge about, Narrative Music in Multimedi (Doctoral thesis). Luleå University of Technology, Department of Music and Media. 